Article

\title{
Effect of Mg Treatment on the Nucleation and Ostwald Growth of Inclusions in Fe-O-Al-Mg Melt
}

\author{
Yutang $\mathrm{Li}^{1}{ }^{1}$, Linzhu Wang ${ }^{1, *}$, Chaoyi Chen ${ }^{1}$, Junqi $\mathrm{Li}^{1}$ and Xiang $\mathrm{Li}^{2}$ \\ 1 School of Materials and Metallurgy, Guizhou University, Guiyang 550025, China; \\ DomYutangLi@163.com (Y.L.); ccy197715@126.com (C.C.); jqli@gzu.edu.cn (J.L.) \\ 2 College of Materials \& Metallurgical Engineering, Guizhou Institute of Technology, Guiyang 550003, China; \\ lixiang8656@163.com \\ * Correspondence: lzwang@gzu.edu.cn
}

Received: 30 June 2020; Accepted: 27 July 2020; Published: 28 July 2020

check for updates

\begin{abstract}
This study aimed to investigate the effect of $\mathrm{Mg}$ treatment on the nucleation and ostwald growth of inclusions. Deoxidized experiments with $\mathrm{Al}(0.05 \% \mathrm{Al})$ and $\mathrm{Al}-\mathrm{Mg}(0.05 \% \mathrm{Al}+0.03 \% \mathrm{Mg})$ were carried out at $1873 \mathrm{~K}$, and the composition, number, and size of inclusions were studied as a function of holding time. Homogeneous nucleation theory and ostwald ripening were utilized to calculate the nucleation rate, the critical size of nuclei, and coarsening rate of inclusions. The results show that small inclusions were more easily found in the steels with Al-Mg complex deoxidation, and the number of inclusions with Al-Mg complex deoxidation is larger at an early stage of deoxidation. The critical size of nuclei increases in the order of $\mathrm{MgAl}_{2} \mathrm{O}_{4}(0.3-0.4 \mathrm{~nm})<\mathrm{Al}_{2} \mathrm{O}_{3}(0.4-0.6 \mathrm{~nm})$, and the nucleation rate increases in the order of $\mathrm{Al}_{2} \mathrm{O}_{3}\left(1100 \mathrm{~cm}^{-3} \mathrm{~s}^{-1}\right)<\mathrm{MgAl}_{2} \mathrm{O}_{4}\left(1200 \mathrm{~cm}^{-3} \mathrm{~s}^{-1}\right)$, which is consistent with the experimental results. Moreover, the coarsening rate of $\mathrm{MgAl}_{2} \mathrm{O}_{4}$ inclusions was smaller than $\mathrm{Al}_{2} \mathrm{O}_{3}$ inclusions in both the value of $k_{d(c a l .)}$ from ostwald growth and the value of $k_{d(o b s .)}$ from inclusion size. The effect of $\mathrm{Mg}$ addition on coarsening of inclusion was analyzed and their mechanism was discussed based on ostwald ripening theory and Factsage calculation.
\end{abstract}

Keywords: Mg treatment; inclusion; nucleation; growth; holding time (second)

\section{Introduction}

Nonmetallic inclusions are frequently reported as the origins of steel performance issues. The control of inclusions is one of the main tasks of steelmakers during the production process to improve the mechanical properties, processing properties, and service life of steel. It is found that the small oxide inclusions with uniform distribution can induce nucleation of intragranular ferrite effectively, which will improve the mechanical properties of steel [1,2]. Due to its strong deoxidization ability and low price, aluminum become the most popular deoxidizer applied in the modern steelmaking process. Nevertheless, the generated $\mathrm{Al}_{2} \mathrm{O}_{3}$ inclusions tend to aggregate and form large clusters that are detrimental to the mechanical properties of steel and easily cause nozzle clogging [3,4]. Therefore, calcium treatment is often applied during refining to modify $\mathrm{Al}_{2} \mathrm{O}_{3}$ inclusions into low-melting calcium aluminates, which is an effective method to prevent the inclusions from clogging the nozzles [5-7]. However, it is reported that large size inclusions still can be detected in steel after calcium treatment and these inclusions will be prolonged to tens of microns long after rolling [8]. Hence, a large number of studies were carried out to solve this problem and it was found that $\mathrm{Mg}$ treatment has a significant improvement on the steel performances [9-12]. Lots of inclusions with small size have been observed in the steels with $\mathrm{Mg}$ treatment, and it is found that $\mathrm{Mg}$ treatment facilitates the increase of inclusion number and the degree of homogeneity in inclusion dispersion [13-16]. Fu et al. [12] comparatively studied 35CrNi3MoV steel with Al deoxidized and 
$\mathrm{Al}-\mathrm{Mg}$ complex deoxidized and found that $\mathrm{Mg}$ treatment is conducive to decrease of inclusion size. Kimura et al. [17] observed that $\mathrm{MgO}$ and $\mathrm{MgAl}_{2} \mathrm{O}_{4}$ inclusions had a much weaker tendency to coagulate and form clusters via confocal scanning laser microscope. Though lots of studies about $\mathrm{Mg}$ treatment have been done, almost all of these studies only revealed phenomenon observed at experiences. The present study explores the nucleation and growth of inclusions.

In the view of controlling size and number of inclusions, the nucleation and growth of inclusions during the deoxidation process in the steel must be considered. Suito and Ohta et al. [18] found that the inclusions are deemed to grow and coarsen by the following steps: the diffusion of reactants to the oxide nuclei, Ostwald ripening, collision, and subsequent coagulation in liquid metal. Kluken [19] and Suzuki et al. [20] concluded that the growth of inclusions in steel should be explained by Ostwald ripening. In spite of extensive studies on formation mechanism and composition analysis [21-25], there are limited studies on nucleation and growth of inclusions containing $\mathrm{Mg}$.

In the current study, the number and size of inclusions were analyzed in $\mathrm{Al}$ deoxidized steel and $\mathrm{Al}-\mathrm{Mg}$ complex deoxidized steel. In addition, the critical nucleation size, nucleation rate, and coarsening rate were calculated based nucleation theory, Ostwald ripening theory, and thermodynamics calculation by FACTSAGE (FACTSAGE (FACTSAGE7.2, Thermfact/CRCT and GTT-Technologies, Montréal and herzogenrath, Canada and Germany) is a thermodynamic calculation software, which is made joint development by McGill University and ecole Polytechniquede Montreal. It combined Facility for the Analysis of Chemical Thermodynamics (FACT-Win) with SOLGASMIX (ChemSage, (ChemSage, GTT-Technologies, herzogenrath, Germany) in 2001 and named as FACTSAGE.). The present study explores the nucleation and growth of inclusions at deoxidized experiments with $0.05 \% \mathrm{Al}$ and $0.05 \% \mathrm{Al}$ $+0.03 \% \mathrm{Mg}$ ). In addition, the effect of $\mathrm{Mg}$ addition on coarsening of inclusion was analyzed and their mechanism was discussed based on Ostwald ripening theory and Factsage calculation. This study will provide information to understand the relations among characteristics, nucleation, and coarsening of inclusions in Fe-O-Al-Mg melt. The conclusions will be helpful for predicting and controlling size of inclusions.

\section{Experimental}

\section{Experimental Procedure}

In the current study, YT01 pure iron was applied as raw material, and chemical compositions are shown in Table 1. The detailed experimental methods in this work have been described in Wang's paper [15].

Table 1. Chemical compositions of mother steel (weight percent).

\begin{tabular}{cccccccccccc}
\hline Element & $\mathbf{C}$ & $\mathbf{S i}$ & $\mathbf{M n}$ & $\mathbf{P}$ & $\mathbf{S}$ & $\mathbf{C r}$ & $\mathbf{A l}$ & $\mathbf{C u}$ & $\mathbf{N i}$ & $\mathbf{T i}$ & $\mathbf{N}$ \\
\hline Content & 0.0016 & 0.0033 & 0.01 & 0.0053 & 0.0017 & 0.0107 & 0.003 & 0.0037 & 0.0038 & 0.001 & 0.0020 \\
\hline
\end{tabular}

In melting experiments, the Si-Mo heating electric resistance furnace(Braveman Special Testing Furnace CO. LTD., Luoyang, Henan, China) was applied. YT01 pure iron material was enclosed in the $\mathrm{Al}_{2} \mathrm{O}_{3}$ crucible. Meanwhile, the melt was full of Ar gas flowing atmosphere for homogeneity completely, and the melt was held for $30 \mathrm{~min}$ after being heated to $1873 \mathrm{~K}\left(1600{ }^{\circ} \mathrm{C}\right)$. Then, the $\mathrm{Al}$ powder and $\mathrm{Ni} / \mathrm{Mg}$ alloy packed in iron foil were added immediately. In order to disperse the inclusions uniformly, the melt was stirred by a molybdenum rod for $10 \mathrm{~s}$. The experimental samples were taken by a quartz tube at 120,600, and $1800 \mathrm{~s}$ after deoxidizer addition, followed by quenching in salt water. Before being inserted into the molten steel, the quartz tube was injected with Ar gas to prevent reoxidation of samples. 


\section{Measurement of Inclusions}

The main chemical compositions of steel melt, as shown in Table 2, were determined by fusion-infrared absorption and ICP-AES(Inductively Coupled Plasma-Atomic Emission Spectrometry) method. The total oxygen contents in the samples were determined by fusion-infrared absorption, and each sample was measured three times. Total $\mathrm{Al}$, soluble $\mathrm{Al}$, and total $\mathrm{Mg}$ contents in steel were analyzed by the ICP-AES method. The dissolved oxygen was calculated by FACTSAGE7.2 based on the chemical composition of melts.

Table 2. Chemical composition of melt.

\begin{tabular}{|c|c|c|c|c|c|c|c|}
\hline \multirow{3}{*}{ Deoxidizer } & \multirow{3}{*}{$\begin{array}{l}\text { Holding } \\
\text { Time }\end{array}$} & \multirow{2}{*}{$\begin{array}{c}{[\mathrm{O}]} \\
\text { Total }\end{array}$} & \multicolumn{3}{|c|}{ [Al] } & \multicolumn{2}{|c|}{$[\mathrm{Mg}]$} \\
\hline & & & Sol. & Sol. & Insol. & Sol. & Insol. \\
\hline & & (Mass ppm) & (Mass ppm) & (Mass ppm) & (Mass ppm) & (Mass ppm) & (Mass ppm) \\
\hline \multirow{3}{*}{$0.05 \% \mathrm{Al}$} & $600 \mathrm{~s}$ & $90.9-92.8$ & 3.6 & - & - & - & - \\
\hline & $1800 \mathrm{~s}$ & $14.7-117$ & 3.38 & 280 & 79 & - & - \\
\hline & $120 \mathrm{~s}$ & 208 & 4.08 & 390 & 85 & 8-19 & - \\
\hline $0.05 \% \mathrm{Al}+0.03 \% \mathrm{Mg}$ & $1800 \mathrm{~s}$ & 63 & 2.93 & 350 & 23 & 5 & - \\
\hline
\end{tabular}

ppm means parts per million. Sol. for [Al]/[Mg] means soluble [Al]/[Mg] in acid. Insol. for [Al]/[Mg] means insoluble $[\mathrm{Al}] /[\mathrm{Mg}]$ in acid.

In order to analyze characteristics of inclusions, 169 SEM microphotographs $(13 \times 13)$ were taken in each sample. The planar size and number of inclusions were analyzed by Image-Pro Plus software (Image-Pro Plus6.0, Rockville, Media Cybernetics, MD, USA). Due to the limitation of resolution, the small inclusions within $200 \mathrm{~nm}$ have not been analyzed.

\section{Results and Discussion}

\subsection{Composition and Morphologies of Inclusion}

SEM-EDS was used for detecting compositions of 50 inclusions in samples at 120, 600, and $1800 \mathrm{~s}$. As shown in Figure 1, the average content of $\mathrm{MgO}$ in inclusions at 120, 600, and $1800 \mathrm{~s}$ was $19.3 \%$, $19.7 \%, 18.8 \%$, respectively. According to the $\mathrm{Al}_{2} \mathrm{O}_{3}-\mathrm{MgO}$ phase diagram [26] at $1873 \mathrm{~K}\left(1600{ }^{\circ} \mathrm{C}\right)$, inclusions exist as $\mathrm{Al}_{2} \mathrm{O}_{3}+$ spinel, spinel, and spinel $+\mathrm{MgO}$ when $\mathrm{MgO}$ is below $16 \%$, in the range $16 \%$ to $28 \%$ and above $28 \%$, respectively. In the current work, deoxidation product with $\mathrm{Al}-\mathrm{Mg}$ were $\mathrm{MgAl}_{2} \mathrm{O}_{4}$ inclusions.

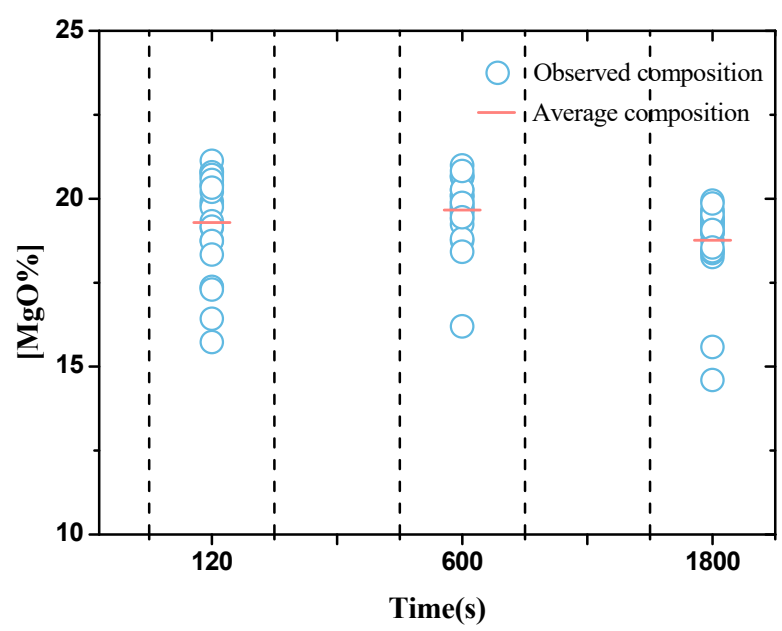

Figure 1. Composition of inclusions in steel with holding time. 
The morphologies of typical inclusions of $\mathrm{Al}_{2} \mathrm{O}_{3}$ and $\mathrm{MgAl}_{2} \mathrm{O}_{4}$ as shown at Figure 2. It is obvious that $\mathrm{Al}_{2} \mathrm{O}_{3}$ inclusions are easy to aggregate, while $\mathrm{MgAl}_{2} \mathrm{O}_{4}$ inclusions have a weaker tendency to aggregate. In addition, the size of $\mathrm{Al}_{2} \mathrm{O}_{3}$ inclusions are larger than $\mathrm{MgAl}_{2} \mathrm{O}_{4}$ inclusions.

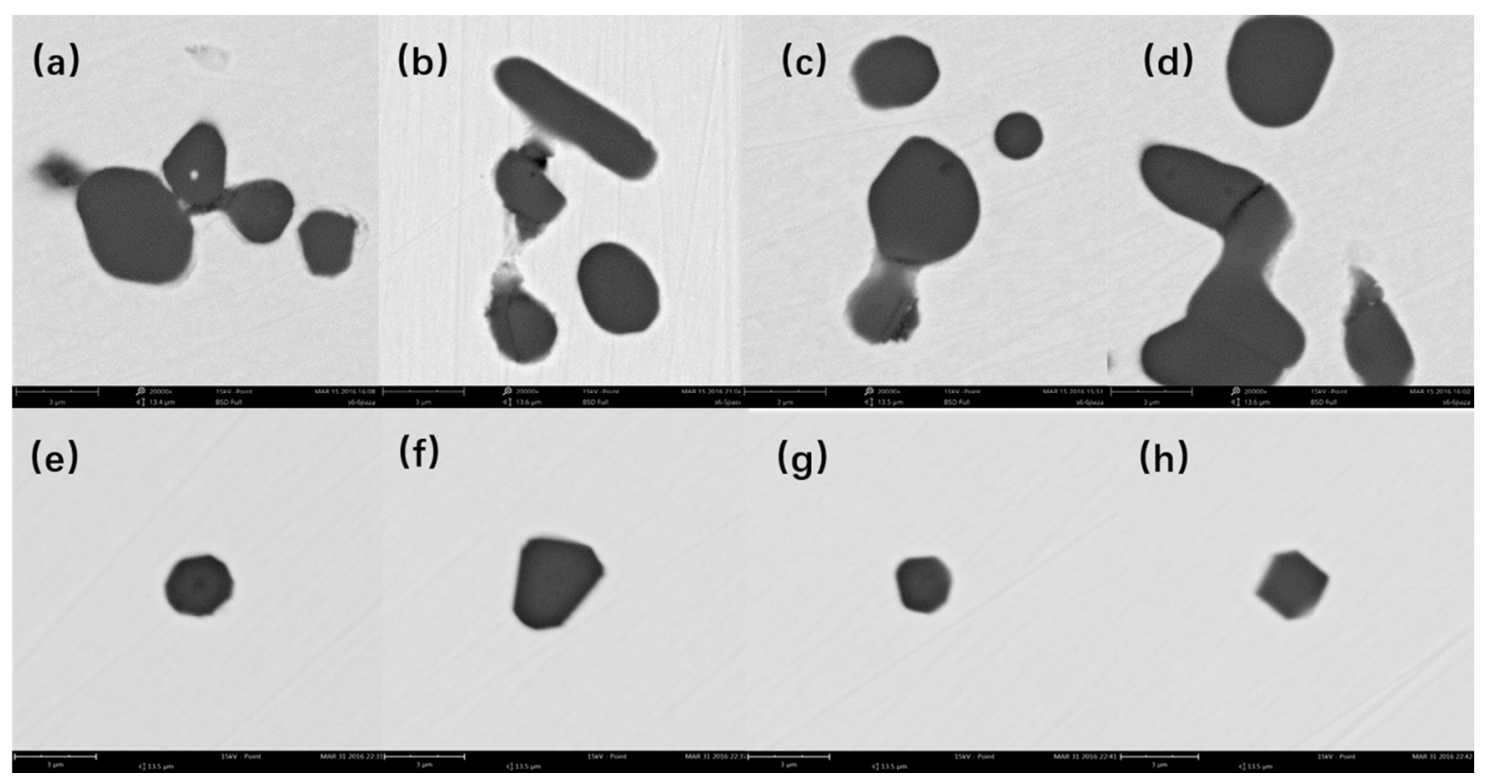

Figure 2. Morphologies of typical inclusions in samples by SEM: $\mathrm{Al}_{2} \mathrm{O}_{3}(\mathbf{a}-\mathbf{d}) ; \mathrm{MgAl}_{2} \mathrm{O}_{4}(\mathbf{e}-\mathbf{h})$.

\subsection{Characteristics of Inclusions}

The two-dimensional size distribution of inclusions as a function of the holding time with $\mathrm{Al}$ deoxidation and with Al-Mg complex deoxidation are shown in Figure 3. $N_{A}$ represents the number density in a certain range of inclusion size and it is obtained by calculating the quotient of the number of inclusions in a sample and the area of sample. Based on references [18,25], the inclusion size distribution tends to be log-normal curves. It is close to log-normal distribution for inclusions with $\mathrm{Al}$ deoxidation, but half-normal curves for inclusions with Al-Mg complex deoxidation at $120 \mathrm{~s}$, which indicates that the inclusions were smaller than $0.2-\mu \mathrm{m}$ generates with Al-Mg complex deoxidation at $120 \mathrm{~s}$. Meanwhile, the small inclusions with Al-Mg complex deoxidation generate indicates that the initial size of inclusions were small and the critical size of nuclei was small. After deoxidation for $120 \mathrm{~s}$, the number density with Al-Mg complex deoxidation at the range from $0.2-0.6 \mu \mathrm{m}$ is approximately equal to the number density with $\mathrm{Al}$ deoxidation. Therefore, there is a slight difference in the number of inclusions between $\mathrm{Al}$ deoxidation and $\mathrm{Al}-\mathrm{Mg}$ complex deoxidation, which indicates that the nucleation rate of inclusions with $\mathrm{Al}-\mathrm{Mg}$ complex deoxidation is close to the nucleation rate of inclusions with $\mathrm{Al}$ deoxidation. However, compared with inclusions deoxidated by $\mathrm{Al}$, the number density of large size inclusions is lower with Al-Mg complex deoxidation at 120, 600, and $1800 \mathrm{~s}$, respectively. It shows that inclusions with $\mathrm{Al}$ deoxidation are easy to coarse. In addition, it is found that the proportion of large size inclusions increases with the holding time as a result of growth or collision. There were inclusions with $4.6 \mu \mathrm{m}$ with $\mathrm{Al}$ deoxidation at holding time of $120 \mathrm{~s}$, it suggests that $\mathrm{Al}_{2} \mathrm{O}_{3}$ inclusions aggregated rapidly. 

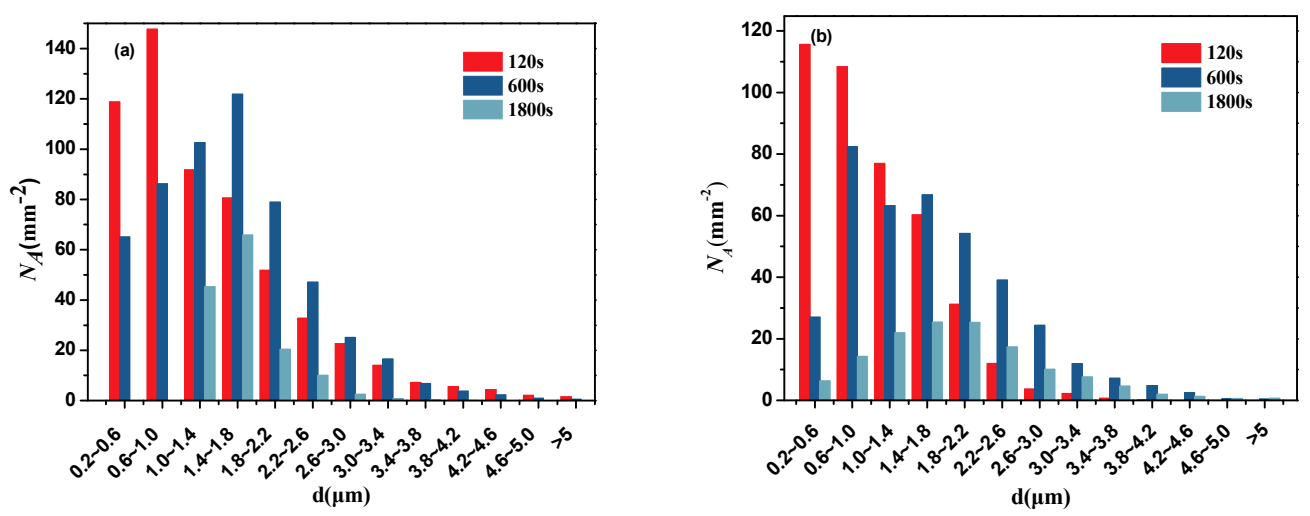

Figure 3. Two-dimensional size distribution of inclusions as a function of holding time. (a) Al deoxidation, (b) Al-Mg complex deoxidation.

Figure 4 shows that the average size of inclusions increases generally, and the number of inclusions decreases with holding time elapsed. After deoxidation for $120 \mathrm{~s}$, the average size of inclusions with $\mathrm{Al}$ deoxidation is 1.3 times as many as inclusions with Al-Mg complex deoxidation, which indicates that the critical size of nuclei of inclusions with Al-Mg complex deoxidation is smaller than inclusions with $\mathrm{Al}$ deoxidation. Though the number of inclusions deoxidated by Al-Mg is lower than those deoxidated by $\mathrm{Al}$, as shown in Figure 4, the inclusion size distribution tends to be half-normal curves for inclusions with Al-Mg complex deoxidation, as shown in Figure 3b. Therefore, the actual number of inclusions with Al-Mg complex deoxidation is approximately 2 times as many as the observed inclusions shown in Figure 4, which indicates that the number of inclusions deoxidated by Al-Mg is larger than those by Al. In addition, at the process from $600 \mathrm{~s}$ to $1800 \mathrm{~s}$, the average size increases by 0.2 with Al-Mg complex deoxidation and 0.5 with $\mathrm{Al}$ deoxidation, respectively, which indicates that the coarsening rate of inclusions with $\mathrm{Al}$ deoxidation is larger than inclusions with Al-Mg complex deoxidation. However, at the process from $120 \mathrm{~s}$ to $1800 \mathrm{~s}$, the rate of increase for average size with $\mathrm{Al}$ deoxidation is larger than inclusions with $\mathrm{Al}-\mathrm{Mg}$ complex deoxidation as a result of flotation of large size $\mathrm{Al}_{2} \mathrm{O}_{3}$ inclusions.
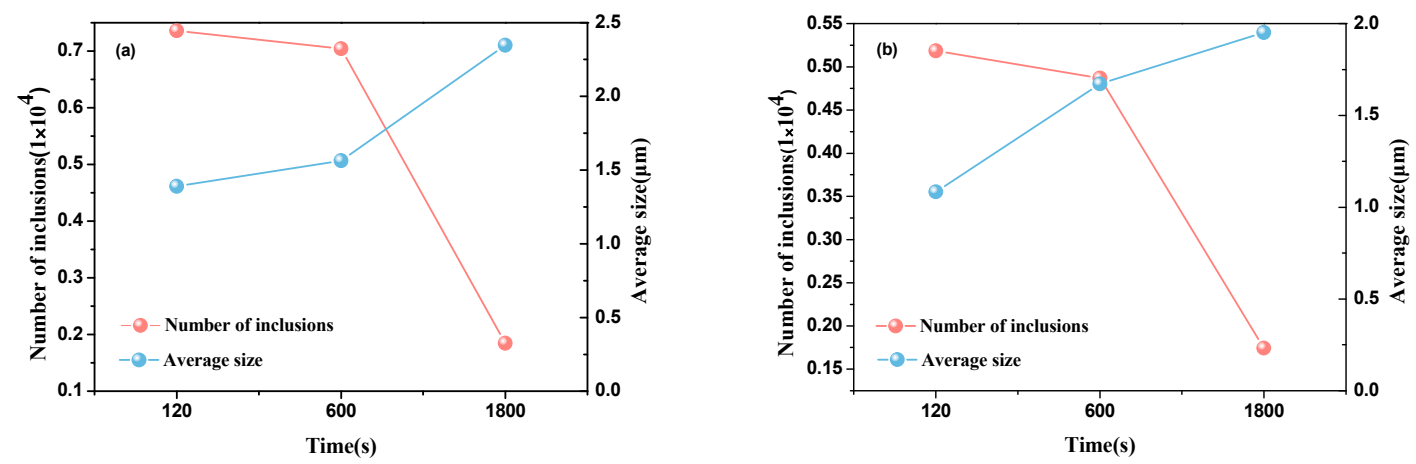

Figure 4. The number and the average size of inclusions as function of holding time. (a) Al deoxidation, (b) Al-Mg complex deoxidation.

It is concluded that small inclusions were more easily found in the steels with $\mathrm{Al}-\mathrm{Mg}$ complex deoxidation. The size distribution of inclusions shows that the inclusions smaller than $0.2 \mu \mathrm{m}$ generate with $\mathrm{Al}-\mathrm{Mg}$ complex deoxidation at $120 \mathrm{~s}$. The average size of inclusions increases generally, and the number of inclusions decreases with holding time elapsed. At early stage of deoxidation, the number of inclusions deoxidated by $\mathrm{Al}-\mathrm{Mg}$ is larger than by $\mathrm{Al}$, which indicates that the nucleation rate of inclusions with $\mathrm{Al}-\mathrm{Mg}$ complex deoxidation is larger than inclusions with $\mathrm{Al}$ deoxidation, and the smaller average size of inclusions with $\mathrm{Al}-\mathrm{Mg}$ complex deoxidation indicates that the critical size of nuclei (the critical size that transfers unstable embryos into stable nuclei) is smaller with $\mathrm{Al}-\mathrm{Mg}$ complex deoxidation. In addition, the larger change of inclusion size with $\mathrm{Al}$ deoxidation indicates 
that the coarsening rate of inclusions with $\mathrm{Al}$ deoxidation is larger. The lower number density of large size inclusions with Al-Mg complex deoxidation at 120,600, and 1800 s, respectively, indicates that inclusions with $\mathrm{Al}$ deoxidation are easy to coarse.

\section{Calculation}

\subsection{Calculated Nucleation Rate and Critical Size of Nuclei}

In order to study the contents of $\mathrm{Al}, \mathrm{Mg}$, and $\mathrm{O}$ on the nucleation rate, $I\left(\mathrm{~cm}^{-3} \mathrm{~s}^{-1}\right)$ was estimated as the following relationship based on the classical nucleation theory [18]:

$$
\ln I=\frac{16 \pi \gamma_{\mathrm{SL}}^{3} \mathrm{~V}_{\mathrm{O}}^{2}}{3 \mathrm{k}_{\mathrm{B}} \mathrm{R}^{2} \mathrm{~T}^{3}}\left(\frac{1}{\left(\ln S_{\mathrm{O}}^{*}\right)^{2}}-\frac{1}{\left(\ln S_{\mathrm{O}}\right)^{2}}\right)
$$

where $V_{O}$ is the molar volume of oxide $\left(\mathrm{m}^{3} / \mathrm{mol}\right) ; \mathrm{S}_{\mathrm{O}}^{*}$ is the critical supersaturation degree, which is value of $S_{O}$ at $I=1 \mathrm{~cm}^{-3} \mathrm{~s}^{-1} ; k_{B}$ is the Boltzman constant $\left(1.38 \times 10^{-23} \mathrm{~J} / \mathrm{K}\right) ; R$ is the gas constant $\left(8.314 \mathrm{~J} \cdot \mathrm{mol}^{-1} \cdot \mathrm{K}^{-1}\right)$; and $T$ is the absolute temperature $(\mathrm{K})$.

Based on classic homogeneous nucleation theory, the critical size of nucleation $r_{C}$ [18] is given by

$$
r_{C}=-\frac{2 \gamma_{S L}}{\Delta G_{V}}=\frac{2 r_{S L} V_{O}}{R T \ln S_{O}} .
$$

$\gamma_{S L}$ is the interfacial energy between oxide and liquid steel $\left(\mathrm{J} / \mathrm{m}^{2}\right)$, and it can be expressed by Young's Equation:

$$
\begin{gathered}
\gamma_{S L}=\gamma_{S V}-\gamma_{L V} \cos \theta, \\
\gamma_{L V}=\gamma_{O}-\sum \gamma_{F e^{\prime}}^{i} \\
\gamma_{O}=2.858-0.000591 \mathrm{~T},
\end{gathered}
$$

where $\gamma_{S V}$ is the surface energy of solid inclusion, $\gamma_{L V}$ is the surface energy of the liquid steel, $\theta$ is the contact angle of liquid steel on solid oxide, $\gamma_{O}$ energy of pure liquid iron, and $\gamma_{F e}^{i}$ is the effect of steel composition on the surface energy of the liquid steel. Substituting the relevant data in Tables 1 and 3 , the following relationship is derived:

$$
\gamma_{L V}=1.75-0.279 \ln \left(1+140 \times a_{O}\right)
$$

Table 3. Effect of steel composition on surface energy of liquid steel $\left(\mathrm{J} / \mathrm{m}^{2}\right)$.

\begin{tabular}{ccccccc}
\hline Element & $\mathbf{C}$ & $\mathbf{S i}$ & $\mathbf{M n}$ & $\mathbf{P}$ & $\mathbf{N}$ & $\mathbf{A l}$ \\
\hline$\gamma_{\mathrm{Fe}}^{\mathrm{i}}$ & $\begin{array}{c}0.065[\mathrm{C} \mathrm{pct}] \\
{[27]}\end{array}$ & $\begin{array}{c}0.026[\mathrm{Si} \mathrm{pct}] \\
{[28]}\end{array}$ & $\begin{array}{c}0.05[\mathrm{Mn} \mathrm{pct}] \\
{[28]}\end{array}$ & $\begin{array}{c}0.025[\mathrm{P} \mathrm{pct}] \\
{[28]}\end{array}$ & $\begin{array}{c}5.585[\mathrm{~N} \mathrm{pct}] \\
{[28]}\end{array}$ & $\begin{array}{c}0.037[\mathrm{Al} \text { pct }] \\
{[28]}\end{array}$ \\
\hline Element & $\mathbf{C r}$ & $\mathbf{C u}$ & $\mathbf{N i}$ & $\mathbf{S}$ & $\mathbf{O}$ \\
\hline$\gamma_{\mathrm{Fe}}^{\mathrm{i}}$ & $\begin{array}{c}0.008[\mathrm{Cr} \text { pct }] \\
{[28]}\end{array}$ & $\begin{array}{c}0.026[\mathrm{Cu} \\
\mathrm{pct}][28]\end{array}$ & $\begin{array}{c}0.002[\mathrm{Ni} \mathrm{pct}] \\
{[28]}\end{array}$ & $\begin{array}{c}0.2 \ln (1+330[\mathrm{pct} \\
\mathrm{S}])[29]\end{array}$ & $\begin{array}{c}0.279 \\
\ln \left(1+140\left[a_{\mathrm{O}}\right]\right) \\
{[30]}\end{array}$ \\
\hline
\end{tabular}

pct is abbreviation for per cent.

The calculated critical size of nuclei and nucleation rate for oxide inclusions at $1873 \mathrm{~K}\left(1600{ }^{\circ} \mathrm{C}\right)$ are shown in Figure 5. The critical size of nuclei is obtained by substituting Equation (3) and relevant data in Table 4 to Equation (2), and then the value of $S_{O}$ is known when the $r_{C}$ is a certain value.

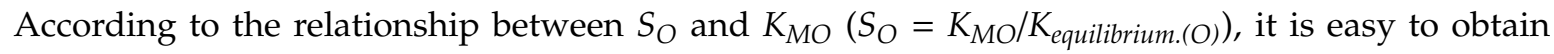
the relationship between $a_{O}$ and $K_{M O}$, as shown in Figure 5. $K_{\text {eq.(O) }}$ is the equilibrium constant per 
mole oxide, as shown in Table 5 , and the $K_{M O}$ is solubility product per mole oxide $\left(K_{M O}=a_{M} 1 / \mathrm{X} a_{O}\right.$, in this work, $\left.K_{A l 2 O 3}=a_{A l} 2 / 3 a_{O}, K_{M g A l 2 O 4}=a_{M g} 1 / 4 a_{A l} 1 / 2 a_{O}, K_{M g O}=a_{M g} a_{O}\right)$. The method to obtain the nucleation rate is similar to the critical size of nuclei by substituting relevant data to Equation (1). In Figure 5, the red dotted lines are the critical size of nuclei, the blue solid lines are the nucleation rate and the black spherical marks are the $r_{C}$ and $\ln I$ value based on the compositions of experimental melts. The calculated results show that there is little difference in the critical size of nuclei for $\mathrm{Al}_{2} \mathrm{O}_{3}, \mathrm{MgAl}_{2} \mathrm{O}_{4}$, and $\mathrm{MgO}$ with size from 0.1 to $2 \mathrm{~nm}$. It indicates that the nucleation rate is strongly dependent on the activity of oxygen when $a$ o exceeds a certain value and the nucleation rate for $\mathrm{Al}_{2} \mathrm{O}_{3}$, and $\mathrm{MgAl}_{2} \mathrm{O}_{4}$ increases with the increasing $a$ o. The critical size of nuclei for $\mathrm{Al}_{2} \mathrm{O}_{3}$ and $\mathrm{MgAl}_{2} \mathrm{O}_{4}$ decreases with the increasing $a \mathrm{o}$ and $K_{M O}$, and $\mathrm{MgO}$ increases first and then decreases. Based on the compositions of melt, the calculated results show that the critical size of nuclei at holding time of $120 \mathrm{~s}$ increases in the order of $\mathrm{MgAl}_{2} \mathrm{O}_{4}(0.3-0.4 \mathrm{~nm})<\mathrm{Al}_{2} \mathrm{O}_{3}(0.4-0.6 \mathrm{~nm})$ and the nucleation rate increases in the order of $\mathrm{Al}_{2} \mathrm{O}_{3}\left(1100 \mathrm{~cm}^{-3} \mathrm{~s}^{-1}\right)<\mathrm{MgAl}_{2} \mathrm{O}_{4}\left(1200 \mathrm{~cm}^{-3} \mathrm{~s}^{-1}\right)$. At the early stage of deoxidation, the calculated results show that the size of $\mathrm{Al}_{2} \mathrm{O}_{3}$ inclusions is larger than $\mathrm{MgAl}_{2} \mathrm{O}_{4}$ inclusions, and the nucleation number of $\mathrm{MgAl}_{2} \mathrm{O}_{4}$ inclusions is larger than $\mathrm{Al}_{2} \mathrm{O}_{3}$ inclusions.
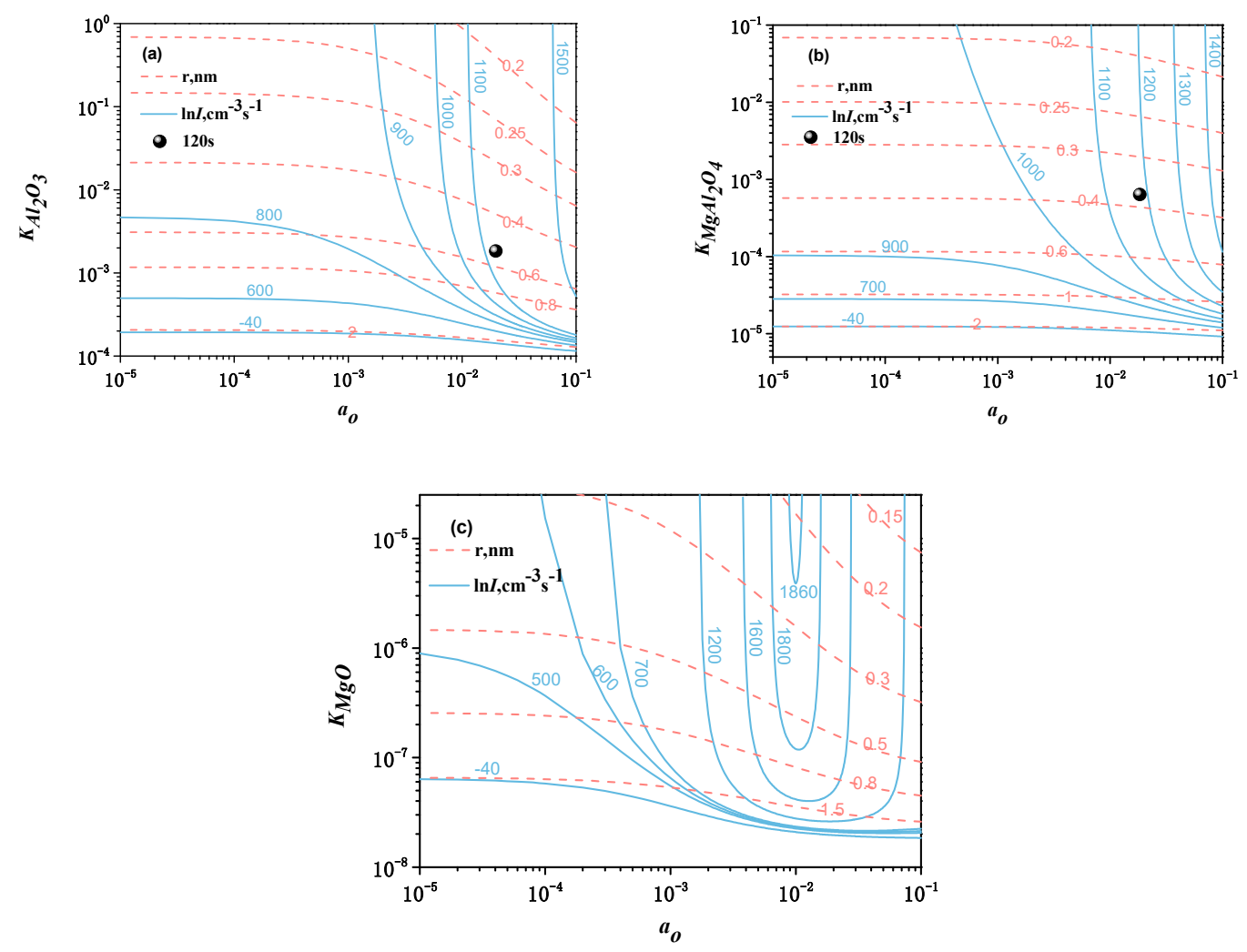

Figure 5. Calculated critical size of nuclei and nucleation rate for oxide inclusions at $1873 \mathrm{~K}:(\mathbf{a}) \mathrm{Al}_{2} \mathrm{O}_{3}$, (b) $\mathrm{MgAl}_{2} \mathrm{O}_{4}$, (c) $\mathrm{MgO}$.

Table 4. Parameters used in the calculation of critical size of nuclei and nucleation rate.

\begin{tabular}{cccc}
\hline Oxide & $\boldsymbol{\Theta}(\mathbf{d e g})$ & $\gamma_{\mathbf{S V}}\left(\mathbf{J} / \mathbf{m}^{\mathbf{2}}\right)$ & $\mathbf{V}_{\mathbf{O}}\left(\mathbf{m}^{\mathbf{3}} / \mathbf{m o l}\right)$ \\
\hline $\mathrm{Al}_{2} \mathrm{O}_{3}$ & $132-6.3 \ln (1+400[$ pctO] $) 0.63 \ln (1+640[\mathrm{pctS}])[29]$ & $1.128-0.0001 \mathrm{~T}[30]$ & $8.6 \times 10^{-6}$ \\
$\mathrm{MgO}$ & $117-7.4 \ln \left(1+720 a_{O}\right)\left(-15<\log a_{O}<9\right)[31]$ & $0.86[32]$ & $11 \times 10^{-6}$ \\
$\mathrm{MgAl}_{2} \mathrm{O}_{4}$ & $105[33]$ & $2.270-0.0006 \mathrm{~T}[34,35]$ & $9.3 \times 10^{-6}$ \\
\hline
\end{tabular}


Table 5. Equilibrium constants used in this study.

\begin{tabular}{cc}
\hline Equation & $\log \mathbf{K}_{\mathbf{e q}}$ \\
\hline $\mathrm{Al}_{2} \mathrm{O}_{3}(\mathrm{~s})=2[\mathrm{Al}]+3[\mathrm{O}]$ & $-12.57=(-45300 / \mathrm{T}+11.62)[36]$ \\
$\mathrm{MgO}(\mathrm{s})=[\mathrm{Mg}]+[\mathrm{O}]$ & $-7.86=(-38059 / \mathrm{T}+12.45)[36]$ \\
$\mathrm{MgAl}_{2} \mathrm{O}_{4}(\mathrm{~s})=[\mathrm{Mg}]+2[\mathrm{Al}]+4[\mathrm{O}]$ & $-21.28=(-84339 / \mathrm{T}+23.75)[36]$ \\
\hline
\end{tabular}

The compositions of melt as shown in Table 2 and the activities of $\mathrm{O}, \mathrm{Al}$, and $\mathrm{Mg}$ are obtained by substituting compositions of melt and relevant thermodynamic data in Table 6 to Equations (7) and (8) [36]. The estimated composition of steels was shown in Table 7.

$$
\begin{aligned}
a_{i} & =f_{i}[\text { mass } \% i], \\
\log f_{i} & =\sum e_{i}^{j}[\text { mass } \% i],
\end{aligned}
$$

where $a_{i}, f_{i}$, and [mass \%i] are the 1 mass $\%$ activity, 1 mass $\%$ activity coefficient, and the concentration of $i$ in mass fraction, respectively. $e_{i}^{j}$ is the first-order interaction coefficient. The calculated results show that the critical size of nuclei of inclusions with $\mathrm{Al}$ deoxidation is larger than inclusions with $\mathrm{Al}-\mathrm{Mg}$ complex deoxidation, and the nucleation rate of inclusions with Al deoxidation is smaller than inclusions with $\mathrm{Al}-\mathrm{Mg}$ complex deoxidation. It is concluded that the calculated results based on homogeneous nucleation theory are consistent with the experimental results.

Table 6. Interaction coefficients of $\mathrm{O}, \mathrm{Al}$, and $\mathrm{Mg}$ at $1873 \mathrm{~K}\left(1600{ }^{\circ} \mathrm{C}\right)$.

\begin{tabular}{cccccccccccccc}
\hline $\mathbf{e}_{i}^{j}(\rightarrow \mathbf{j})$ & $\mathbf{C}$ & $\mathbf{S i}$ & $\mathbf{M n}$ & $\mathbf{P}$ & $\mathbf{S}$ & $\mathbf{C r}$ & $\mathbf{C u}$ & $\mathbf{N i}$ & $\mathbf{T i}$ & $\mathbf{N}$ & $\mathbf{O}$ & $\mathbf{A l}$ & $\mathbf{M g}$ \\
\hline $\mathrm{O}$ & -0.42 & -0.066 & -0.021 & 0.07 & -0.13 & -0.055 & -0.013 & 0.006 & -0.34 & -0.14 & -0.17 & -1.17 & -1.98 \\
$\mathrm{Al}$ & 0.091 & 0.056 & -0.004 & 0.033 & 0.035 & 0.012 & -0.013 & -0.017 & - & 0.015 & -1.98 & 0.043 & -0.13 \\
$\mathrm{Mg}$ & -0.31 & -0.088 & - & - & - & 0.047 & & -0.012 & -0.64 & - & -3 & -0.12 & - \\
\hline
\end{tabular}

Table 7. Estimated composition of steels (weight percent).

\begin{tabular}{ccccccc}
\hline Holding Time & {$[\mathbf{O}]$} & {$[\mathrm{Al}]$} & {$[\mathbf{M g}]$} & $\boldsymbol{a}_{\mathbf{O}}$ & $\boldsymbol{a}_{\mathrm{Al}}$ & $\boldsymbol{a}_{\mathbf{M g}}$ \\
\hline $120 \mathrm{~s}$ & 0.0218 & 0.0310 & 0 & 0.019783 & 0.028190 & 0 \\
$1800 \mathrm{~s}$ & 0.0046 & 0.0280 & 0 & 0.004237 & 0.027531 & 0 \\
$120 \mathrm{~s}$ & 0.0208 & 0.0390 & $0.0008-0.0019$ & 0.018367 & 0.035641 & 0.001154 \\
$1800 \mathrm{~s}$ & 0.0063 & 0.0350 & 0.0005 & 0.005677 & 0.034167 & 0.000473 \\
\hline
\end{tabular}

\subsection{Ostwald Growth}

Based on the research of Ohta [27], the inclusions growth by Ostwald ripening can be expressed by

$$
\begin{gathered}
\bar{r}^{3}-{\overline{r_{0}}}^{3}=k_{d} \times \alpha \times t, \\
k_{d(O)}=\frac{2 \gamma_{S L} D_{O} V_{O} C_{O}}{R T\left(C_{P}-C_{O}\right)},
\end{gathered}
$$

where $\bar{r}$ and $\overline{r_{0}}$ is the mean inclusions radius at time $\mathrm{t}(\mathrm{m})$ and that at the start of Ostwald growth respectively, $k_{d}$ is coarsening rate $\left(\mu \mathrm{m} 3 \cdot \mathrm{s}^{-1}\right), \alpha$ is the coarsening coefficient ( $\alpha=4 / 9$ in LSW theory), $D_{O}$ is the diffusion constant of oxygen $\left(2.91 \times 10^{-9} \mathrm{~m}^{2} / \mathrm{s}\right), C_{O}$ is the dissolved oxygen concentration expressed by weight per unit volume $\left(\mathrm{kg} / \mathrm{m}^{3}\right)$, and $C_{P}$ is the oxygen concentration in oxide expressed by weight per unit volume $\left(\mathrm{kg} / \mathrm{m}^{3}\right)$.

$k_{d(\text { cal. }) /} k_{d(\text { (calculation })}$ from Ostwald growth and $k_{d(\text { obs. }) /} k_{d(\text { observation })}$ from inclusion size was obtained by considering the oxygen diffusion, as shown in Figure 6. $k_{d(\text { obs.) }}$ can be expressed by Equation (9) and $k_{d(c a l .)}$ can be expressed by Equation (10). Figure 6 shows that the coarsening rate of $\mathrm{MgAl}_{2} \mathrm{O}_{4}$ inclusions was smaller than $\mathrm{Al}_{2} \mathrm{O}_{3}$ inclusions whether $k_{d(c a l .)}$ from Ostwald growth or $k_{d(o b s .)}$ from 
inclusion size. Though there are half points lying at line $k_{d(c a l .)}=k_{d(\text { obs. })}$, the difference between $k_{d(c a l .)}$ and $k_{d(o b s .)}$ is controlled within an order of magnitude. In addition, the experimental results show that the number of inclusions decreases sharply from $600 \mathrm{~s}$ to $1800 \mathrm{~s}$ as a result of floatation of large number of inclusions, which affects the calculated results.

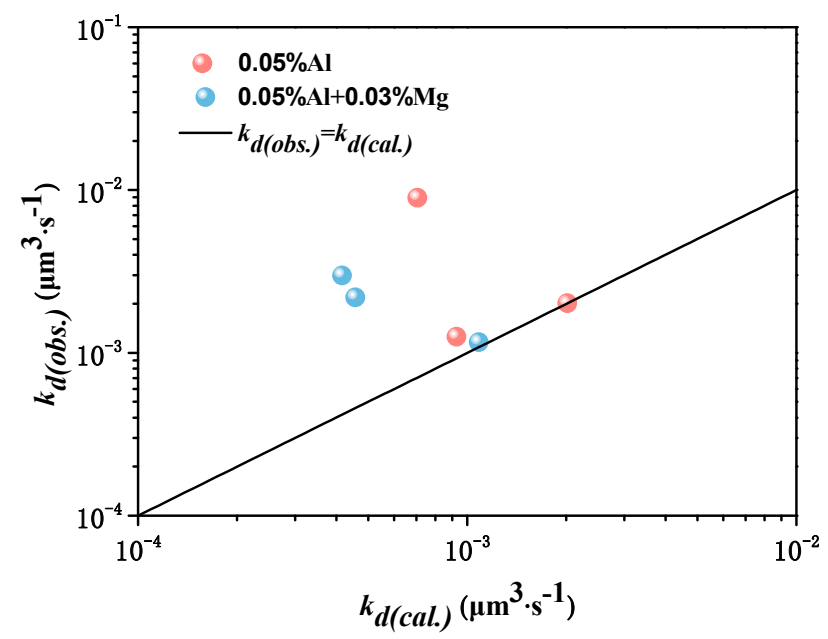

Figure 6. Comparison of $\mathrm{k}_{\mathrm{d}(\mathrm{cal} .)}$ from Ostwald growth and $\mathrm{k}_{\mathrm{d}(\mathrm{obs} .)}$ from inclusion size.

It is necessary to consider the diffusion of deoxidation metal element duo to the same order of magnitude between magnesium content and oxygen content. The effect of $\mathrm{Mg}$ addition on the Ostwald growth of inclusions with [Al] of $0.04 \%$ and $0.03 \%$ was obtained by considering the oxygen diffusion and magnesium diffusion, as shown in Figure 7 . The coarsening rate $k_{d(M g / A l)}$ can be expressed by Equation (11), in which the notations are similar to Equation (10). $D_{M g / A l}$ is assumed to be equal to the $D_{O}$ because the solute diffusivities in liquid Fe are considered to be the same order of magnitude [22].

$$
k_{d(M)}=\frac{2 \gamma_{S L} D_{M} V_{M} C_{M}}{R T\left(C_{P(M)}-C_{M}\right)} .
$$

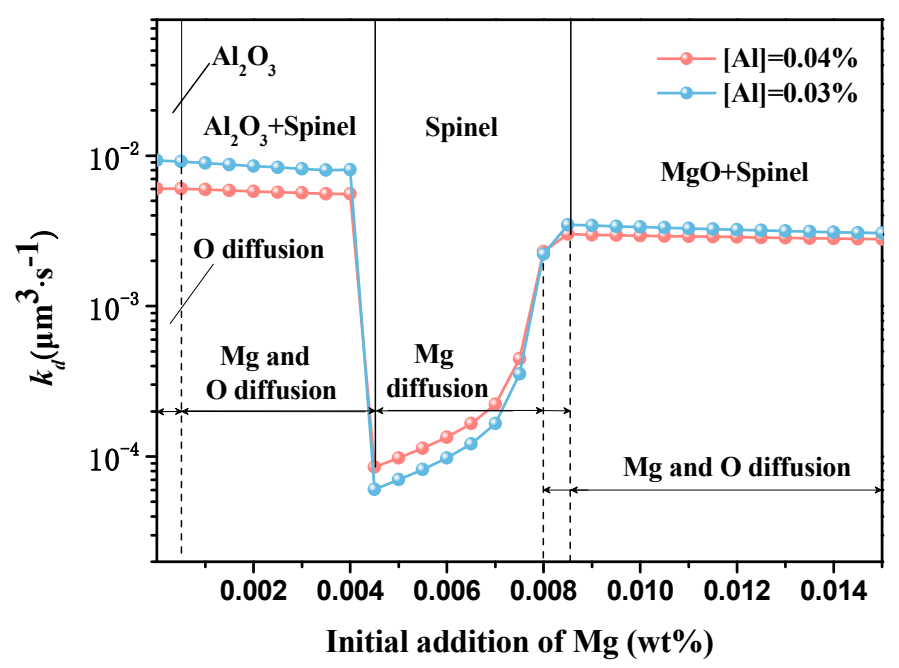

Figure 7. Effect of $\mathrm{Mg}$ addition on coarsening rate caused by Ostwald ripening $\mathrm{k}_{\mathrm{d}}$ of inclusions.

Figure 7 is obtained based on Equations (10) and (11). FACTSAGE7.2 software is used in current study. Equilibrium compositions of melt with $\mathrm{Mg}$ addition are estimated by FACTSAGE7.2 with the FToxid and FTmisc databases (based on the compositions of raw materials). "Equilib" module is used, and pure solids Fe-liq in solution phases are selected as products. Calculated temperature and pressure 
are set as $1600^{\circ} \mathrm{C}$ and $1 \mathrm{~atm}$, respectively. Then, the content of $\mathrm{O}, \mathrm{Al}, \mathrm{Mg}, \mathrm{Al}_{2} \mathrm{O}_{3}$, Spinel, and $\mathrm{MgO}$ are obtained by FACTSAGE7.2. The coarsening rates of $\mathrm{Al}_{2} \mathrm{O}_{3}$, Spinel, and $\mathrm{MgO}$ are the smallest values found by comparing $k_{d(O)}$ and $k_{d(M)}$. The eventual value of $k_{d}$, as shown in Figure 7, is obtained by calculated the sum of products of the percentage of molar mass of $\mathrm{Al}_{2} \mathrm{O}_{3}$, Spinel, and $\mathrm{MgO}$ by the coarsening rates of $\mathrm{Al}_{2} \mathrm{O}_{3}$, Spinel, and $\mathrm{MgO}$, respectively. The coarsening rate of inclusions decreases when the amount of added $\mathrm{Mg}$ under $0.0005 \%$ decreases at the range of $0.0005 \%-0.0045 \%$, increases at the range of $0.0045 \%-0.0085 \%$, and keeps steady beyond $0.0085 \%$. During the four stages shown in Figure 7, the products are $\mathrm{Al}_{2} \mathrm{O}_{3}$ determined by oxygen diffusion; $\mathrm{Al}_{2} \mathrm{O}_{3}+$ Spinel determined by $\mathrm{Mg}$ and oxygen diffusion; Spinel determined by $\mathrm{Mg}$ diffusion; $\mathrm{MgO}+$ Spinel determined by $\mathrm{Mg}$ and oxygen diffusion, respectively. (An explanation must be made between Figures 5 and 7 . The parameters at tables are only used for nucleation calculation as shown in Figure 5, while the parameters in the FToxid and FTmisc databases are only used for coarsening rate calculation preliminarily as shown in Figure 7 . At the section of nucleation calculation, the parameters at tables are derived from Thermodynamic Data for Steelmaking [36], in which the data are new and verified. At the section of coarsening rate calculation, it is difficult to calculate via classical thermodynamics but Factsage7.2 at multicomponent equilibrium. The data in the FToxid and FTmisc databases may not be accurate, but the tendency of calculated results is consistent. In fact, it is worth replacing the data in the FToxid and FTmisc databases with updated data at calculation research, and the Compound module at Factsage7.2 must be used. In future work, the relevant research will be explored.)

\section{Conclusions}

In the current study, experiments and nucleation calculation were performed to investigate the effect of $\mathrm{Mg}$ treatment on nucleation and Ostwald growth in Fe-O-Al-Mg melt. Based on the experimental results and nucleation analysis, the following conclusions were obtained. (1) It is concluded that small inclusions were more easily found in the steels with Al-Mg complex deoxidation. The size distribution of inclusions shows that the inclusions smaller than $0.2 \mu \mathrm{m}$ generate with $\mathrm{Al}-\mathrm{Mg}$ complex deoxidation at $120 \mathrm{~s}$. The average size of inclusions increases generally, and the number of inclusions decreases with holding time elapsed. At early stage of deoxidation, the number of inclusions deoxidated by $\mathrm{Al}-\mathrm{Mg}$ is larger than those by $\mathrm{Al}$, which indicates that the nucleation rate of inclusions with $\mathrm{Al}-\mathrm{Mg}$ complex deoxidation is larger than inclusions with $\mathrm{Al}$ deoxidation, and the smaller average size of inclusions with Al-Mg complex deoxidation indicates that the critical size of nuclei is smaller with Al-Mg complex deoxidation. In addition, the larger change of inclusion size with Al deoxidation indicates that the coarsening rate of inclusions with $\mathrm{Al}$ deoxidation is larger. The lower number density of large size inclusions with Al-Mg complex deoxidation at 120, 600, $1800 \mathrm{~s}$ respectively indicates that inclusions with $\mathrm{Al}$ deoxidation are easy to coarse. (2) The calculated results show that the critical size of nuclei at a holding time of $120 \mathrm{~s}$ increases in the order of $\mathrm{MgAl}_{2} \mathrm{O}_{4}(0.3-0.4 \mathrm{~nm})<\mathrm{Al}_{2} \mathrm{O}_{3}(0.4-0.6 \mathrm{~nm})$. The nucleation rate increases in the order of $\mathrm{Al}_{2} \mathrm{O}_{3}\left(1100 \mathrm{~cm}^{-3} \mathrm{~s}^{-1}\right)<\mathrm{MgAl}_{2} \mathrm{O}_{4}\left(1200 \mathrm{~cm}^{-3} \mathrm{~s}^{-1}\right)$. It is concluded that the calculated results based on homogeneous nucleation theory are consistent with the experimental results. (3) The coarsening rate of $\mathrm{MgAl}_{2} \mathrm{O}_{4}$ inclusions was smaller than $\mathrm{Al}_{2} \mathrm{O}_{3}$ inclusions whether using $k_{d(c a l .)}$ from Ostwald growth or $k_{d(o b s .)}$ from inclusion size. Based on Ostwald ripening theory and Factsage calculation, the effect of $\mathrm{Mg}$ addition on coarsening of inclusion was analyzed and their mechanism was discussed. The coarsening rate of inclusions decreases when the amount of added $\mathrm{Mg}$ is under $0.0005 \%$, decreases at the range of $0.0005 \%-0.0045 \%$, increases at the range of $0.0045 \%-0.0085 \%$, and keeps steady beyond $0.0085 \%$. During four stages, the products are $\mathrm{Al}_{2} \mathrm{O}_{3}$ determined by oxygen diffusion; $\mathrm{Al}_{2} \mathrm{O}_{3}+$ Spinel determined by $\mathrm{Mg}$ and oxygen diffusion; Spinel determined by $\mathrm{Mg}$ diffusion; and $\mathrm{MgO}+$ Spinel determined by $\mathrm{Mg}$ and oxygen diffusion, respectively.

Author Contributions: Conceptualization, Y.L. and L.W.; methodology, L.W., J.L.; software, Y.L. and L.W.; writing-original draft preparation, Y.L., L.W.; writing-review and editing, Y.L., X.L. and C.C.; funding acquisition, L.W., C.C., J.L., X.L. All authors have read and agreed to the published version of the manuscript. 
Funding: This project is s financially supported by the National Science Foundation of China with the grant No. $51804086,51704085,51864013$ and 51704083. Also, this project supported by National Natural Science Foundation of Guizhou Province with grant No. [2019]1086. Program Foundation for Talents of Education department of Guizhou Province with grant No. Qian Jiao He [2018] 105 is gratefully acknowledged.

Conflicts of Interest: The authors declare no conflict of interest.

\section{References}

1. Sarma, D.S.; Karasev, A.V.; Jonsson, P.G. On the role of non-metallic inclusions in the nucleation of acicular ferrite in steels. ISIJ Int. 2009, 49, 1063-1074. [CrossRef]

2. Ishikawa, F.; Takahashi, T.; Ochi, T. Intragranular ferrite nucleation in medium-carbon vanadium steels. Metall. Mater. Trans. A 1994, 25, 929-936. [CrossRef]

3. Van Ende, M.-A.; Guo, M.; Proost, J.; Blanpain, B.; Wollants, P. Formation and morphology of $\mathrm{Al}_{2} \mathrm{O}_{3}$ inclusions at the onset of liquid Fe deoxidation by $\mathrm{Al}$ addition. ISIJ Int. 2011, 51, 27-34. [CrossRef]

4. Braun, T.B.; Elliott, J.F.; Flemings, M.C. The clustering of alumina inclusions. Metall. Trans. B 1979, 10, 171-184. [CrossRef]

5. Verma, N.; Pistorius, P.C.; Fruehan, R.J.; Potter, M.S.; Oltmann, H.G.; Pretorius, E.B. Calcium Modification of Spinel Inclusions in Aluminum-Killed Steel: Reaction Steps. Metall. Mater. Trans. B 2012, 43B, 830-840. [CrossRef]

6. Verma, N.; Pistorius, P.C.; Fruehan, R.J.; Potter, M.S.; Lind, M.; Story, S. Transient Inclusion Evolution During Modification of Alumina Inclusions by Calcium in Liquid Steel: Part I. Background, Experimental Techniques and Analysis Methods. Metall. Mater. Trans. B 2011, 42B, 711-719. [CrossRef]

7. Park, J.H.; Lee, S.-B.; Kim, D.S. Inclusion control of ferritic stainless steel by aluminum deoxidation and calcium treatment. Metall. Mater. Trans. B 2005, 36, 67-73. [CrossRef]

8. Saxena, S.K. Production of ultra-clean steels with better mechanical properties with magnesium treatment. In Proceedings of the Seventy Ninth Conference of the Steelmaking Division of the Iron and Steel Society, Pittsburgh, PA, USA, 24-27 March 1996; pp. 89-96.

9. Miki, Y.; Thomas, B.G. Modeling of inclusion removal in a tundish. Metall. Mater. Trans. B 1999, 30B, 639-654. [CrossRef]

10. Zhang, L.; Taniguchi, S.; Cai, K. Fluid flow and inclusion removal in continuous casting tundish. Metall. Mater. Trans. B 2000, 31B, 253-266. [CrossRef]

11. Zhang, L.; Aoki, J.; Thomas, B.G. Inclusion removal by bubble flotation in a continuous casting mold. Metall. Mater. Trans. B 2006, 37B, 361-379. [CrossRef]

12. Min, Y.; Li, X.; Yu, Z.; Liu, C.; Jiang, M. Characterization of the Acicular Ferrite in Al-Deoxidized Low-Carbon Steel Combined with $\mathrm{Zr}$ and Mg Additions. Steel Res. Int. 2016, 87, 1503-1510. [CrossRef]

13. Lowe, J.H.; Mitchell, A. Clean Steel, Superclean steel. In Proceedings of the Institute of Materials, London, UK, 6-7 March 1995.

14. Fu, J.; Yu, Y.G.; Wang, A.R.; Chen, B.P.; Sun, W.S. Inclusion Modification with Mg Treatment for 35CrNi3MoV Steel. J. Mater. Sci. Technol. 1998, 14, 53-56.

15. Wang, L.; Yang, S.; Li, J.; Zhang, S.; Ju, J. Effect of Mg Addition on the Refinement and Homogenized Distribution of Inclusions in Steel with Different Al Contents. Metall. Mater. Trans. B 2017, 48, 805-818. [CrossRef]

16. Yang, L.; Wang, L.; Yang, M. The Influencing Factor of $\mathrm{MgAl}_{2} \mathrm{O}_{4}$ on Heterogeneous Nucleation and Grain Refinement in Al Alloy Melts. Materials 2020, 13, 231. [CrossRef]

17. Kimura, S.; Nakajima, K.; Mizoguchi, S. Behavior of alumina-magnesia complex inclusions and magnesia inclusions on the surface of molten low-carbon steels. Metall. Mater. Trans. B 2001, 32, 79-85. [CrossRef]

18. Suito, H.; Ohta, H. Characteristics of Inclusion Size Distribution in Early Stage of Deoxidation. ISIJ Int. 2006, 46, 33-41. [CrossRef]

19. Kluken, A.O.P.G. Mechanisms of inclusion formation in Al-Ti-Si-Mn deoxidized steel weld metals. Metall. Mater. Trans. A 1989, 20, 1335-1349. [CrossRef]

20. Suzuki, M.; Yamaguchi, R.; Murakami, K.; Nakada, M. Inclusion Growth during Solidificatio of Stainless Steel. ISIJ Int. 2001, 41, 247-256. [CrossRef] 
21. Zhu, K.; Yang, J.; Wang, R.; Yang, Z. Effect of Mg Addition on Inhibiting Austenite Grain Growth in Heat Affected Zones of Ti-Bearing Low Carbon Steels. J. Iron Steel Res. Int. 2011, 18, 60-64. [CrossRef]

22. Ohta, H.; Suito, H. Effects of dissolved oxygen and size distribution on particle coarsening of deoxidation product. ISIJ Int. 2006, 46, 42-49. [CrossRef]

23. Baumgartner, J.; Dey, A.; Bomans, P.H.; Le Coadou, C.; Fratzl, P.; Sommerdijk, N.A.; Faivre, D. Nucleation and growth of magnetite from solution. Nat. Mater. 2013, 12, 310-314. [CrossRef] [PubMed]

24. Wang, G.C.; Wang, Q.; Li, S.L.; Ai, X.G.; Fan, C.G. Evidence of multi-step nucleation leading to various crystallization pathways from an Fe-O-Al melt. Sci. Rep. 2014, 4, 50-82. [CrossRef]

25. Ohta, H.; Suito, H. Characteristics of Particle Size Distribution of Deoxidation Products with $\mathrm{Mg}, \mathrm{Zr}, \mathrm{Al}, \mathrm{Ca}$, $\mathrm{Si} / \mathrm{Mn}$ and $\mathrm{Mg} / \mathrm{Al}$ in Fe-10mass\%Ni Alloy. ISIJ Int. 2006, 46, 14-21. [CrossRef]

26. Jung, I.H.; Decterov, S.A.; Pelton, A.D. Critical thermodynamic evaluation and optimization of the $\mathrm{MgO}-\mathrm{Al}_{2} \mathrm{O}_{3}$, $\mathrm{CaO}-\mathrm{MgO}-\mathrm{Al}_{2} \mathrm{O}_{3}$, and $\mathrm{MgO}-\mathrm{Al}_{2} \mathrm{O}_{3}-\mathrm{SiO}_{2}$ Systems. J. Phase Equilibria Diffus. 2004, 25, 329-345. [CrossRef]

27. Jimbo, I.; Cramb, A.W. Computer Aided Interfacial Measurements. ISIJ Int. 1992, 32, 26-35. [CrossRef]

28. Keene, B.J. Review of data for the surface tension of iron and its binary alloys. Int. Mater. Rev. 1998, 33, 1-35v. [CrossRef]

29. Poirier, D.R.; Yin, H.; Suzuki, M.; Emi, T. Interfacial Properties of Dilute Fe-O-S Melts on Alumina Substrates. ISIJ Int. 1998, 38, 229-238. [CrossRef]

30. Zhao, L.; Sahajwalla, V. Interfacial phenomena during wetting of graphite/alumina mixtures by liquid iron. ISIJ Int. 2003, 43, 1-6. [CrossRef]

31. Shibata, H.; Jiang, X.; Valdez, M.; Cramb, A.W. The contact angle between liquid iron and a single-crystal magnesium oxide substrate at 1873 K. Metall. Mater. Trans. B 2004, 35B, 179-181. [CrossRef]

32. Humenik, M.; Kingery, W.D. Metal-Ceramic Interactions: III, Surface Tension and Wettability of Metal-Ceramic Systems. J. Am. Ceram. Soc. 1954, 37, 18-23. [CrossRef]

33. Fang, C.M.; Parker, S.C.; de With, G. Atomistic simulation of the surface energy of spinel $\mathrm{MgAl}_{2} \mathrm{O}_{4} . J . A m$. Ceram. Soc. 2000, 83, 2082-2084. [CrossRef]

34. Shibata, H.; Watanabe, Y.; Nakajima, K.; Kitamura, S.Y. Degree of Undercooling and Contact Angle of Pure Iron at $1933 \mathrm{~K}$ on Single-crystal $\mathrm{Al}_{2} \mathrm{O}_{3}, \mathrm{MgO}$, and $\mathrm{MgAl}_{2} \mathrm{O}_{4}$ under Argon Atmosphere with Controlled Oxygen Partial Pressure. ISIJ Int. 2009, 49, 985-991. [CrossRef]

35. Bruce, R.H. Science Ceramics; Stewart, G.H., Ed.; Academic Press: New York, NY, USA, 1965; Volume 2, pp. 359-367.

36. Hino, M.; Ito, K. Thermodynamic Data for Steelmaking, 2nd ed.; Tohoku University Press: Tohoku, Japan, 2010; pp. 247-264.

(C) 2020 by the authors. Licensee MDPI, Basel, Switzerland. This article is an open access article distributed under the terms and conditions of the Creative Commons Attribution (CC BY) license (http://creativecommons.org/licenses/by/4.0/). 